\title{
4949 SAYILI KANUNLA DEĞİŞIK İCRA VE İFLAS KANUNUNA GÖRE ADİ VE REHINLI \\ ALACAKLARIN SIRASI
}

Dr. Adnan DEYNEKLI

\section{PLÂN}

I- Adi ve Rehinli Alacak Kavramı

II- Rehinli Alacaklardan Önce Ödenmesi Gereken Alacaklar

III- Rehinli Alacaklar

IV- Rehinli Olmayan Alacaklardan Önce Ödenmesi Gereken Alacaklar

V- Rehinli Olmayan Alacaklar

1- İmtiyazlı Alacaklar

a- İIKK'nun 206. Maddesinde Öngörülen İmtiyazlı Alacaklar

b- İIK'nun 206. Maddesinde Öngörülmeyen Ancak $\mathrm{Bu}$ Maddede Gireceği Sura Belirtilen Özel Kanunlardan Doğan Alacakların Sırası

2- Adi Alacaklar

VI- Sıralar Arasındaki İlişki 


\section{GİRIŞ}

İflas tasfiyesinin amacı müflisin mevcut malvarlığını tasfiye etmek ve iflasa katılan bütün alacaklıları mümkün olduğu kadar tatmin etmektir. İflas tasfiyesine katılan bir alacağın alacaklı tarafindan münferiden cebri icra yoluyla takip edilmesi mümkün değildir. İflas alacaklıları bu alacaklarını sıra cetveline kaydettirmek suretiyle talep edebilirler. Müflisin aktiflerinin bu taleplerin hepsini tatmin etmesi çok defa mümkün olmayabilir. İflasta prensip alacakların eşit olarak ödenmesi ise de, bu eşitlik mutlak eşitlikten çok adaletin temin edilmesini amaçlayan bir eşitliktir. $\mathrm{Bu}$ nedenle alacakların belli bir sıraya göre tatmin edilmesi düşünülmüş ve sıra düzenine ihtiyaç duyulmuștur. İIK'nun 206. maddesinde adi ve rehinli alacakların sırası düzenlenmiştir. Maddede altı sıra öngörülmüşken 4949 sayılı Kanunla yapılan değişiklik sonucu dört sıra düzenlenmiş, imtiyaz sürelerinin hesabıyla ilgili yeni hükümler getirilmiştir. Bu hüküm haricinde de bazı özel kanunlarda alacakların imtiyazlı olduğu belirtilmiştir. Adi ve rehinli alacakların sırası konusunda yeni düzenlemenin getirdiklerini ortaya koyduktan sonra bir değerlendirme yapacağız.

\section{I- Adi ve Rehinli Alacak Kavramı}

İIK'nın 206. maddesinin kenar başlı̆ğında "adi ve rehinli alacakların sırası" ibaresi kullanılmıştır. Rehinli alacak kavramı bilinen bir kavram olduğu halde adi alacaktan ne kasdedildiği konusunda açıklık yoktur ${ }^{1}$. Maddenin düzenleniş tarzından adi alacak kavramının rehinli alacak kavramının karşıtı olarak kullanıldığı, bu kavramın adi ve imtiyazlı alacakları kapsadığı sonucuna varabiliriz.

Adi alacakları, İIK'nun 206. maddesinde dört sıra halinde öngörülen alacaklar ve İIK'nun 206. maddesinde öngörülmeyen özel konulardan doğan alacaklar olarak tasnife tabi tutabiliriz.

Rehinli alacaklar, mülkiyeti müflise ait malın rehni ile temin edilmiş olan alacaklardır'. İIK' nun 206. maddesinde yer alan rehin kavramından ne anlaşılması gerektiği, aynı Kanun'un 23. maddesinde belirtilmiştir. Hükme göre, sadece rehin tabiri ipotek ve taşınır tabirlerine giren bütün taşınır ve taşınmaz rehinlerini ihtiva eder (İ̈K m. 23/3). Rehnin akdi veya kanuni olması arasında fark bulunmamaktadır ${ }^{3}$.

Adi ve rehinli alacakların sırası yönünden aşağıdaki gibi bir tasnife tabi tutarak sıralama yapmak mümkün bulunmaktadır.

${ }^{1}$ Kuru, Baki: İcra ve İflas Hukuku C. III Ankara 1993, s. 3003.

${ }^{2}$ Kuru, C. III, s. 3003.

${ }^{3}$ Ansay, Sabri Şakir: Hukuk İcra İflas Usulleri Ankara 1956 s. 257. 


\section{II- Rehinli Alacaklardan Önce Ödenmesi Gereken Alacaklar}

Kanunkoyucu iflas tasfiyesinin özelliği gereği bazı alacakların öncelikle ödeneceğini kabul etmiştir. Bu alacaklardan bir kısmı rehinli alacaklardan da önce ödenmesi gereken alacaklardır. Bu alacaklar İIK'nın 248. maddesi ve diğer bazı kanunlarda belirtilmiştir. Eşya ve gayrimenkulun aynından doğan vergi alacağı (İ̈K m. 206/1, 6183 sayılı Yasa m. 21/2), rehinli malın muhafaza ve satış masrafları (İ̈K m. 248), masada gemi varsa gemi alacaklısı hakk1 (TTK m. 1235; 1257) ve Medeni Kanunun 865, 867 ve 877 maddelerinden doğan alacaklar, rehinli alacaklardan da önce ödenmelidir.

Uygulamadaki önemi nedeniyle gemi alacaklısı hakkına kısaca değinmek istiyorum.

Gemi alacaklısı hakkı, alacaklının alacağını deniz servetinden öncelikle olmasını sağlayan bir kanuni rehin hakkıdır.

Gemi alacaklısı hakk1 bulunan alacaklıların, bu hak kapsamında bulunan gemi, gayrisafi navlun ve sürastarya üzerine haciz koydurmalarının bir yararı yoktur. Zira bu hak kanundan doğduğundan ve tescilsiz kazanıldığından haciz tarihlerinin sıra cetvelinde önemi bulunmamaktadır. İhale bedeli paylaştırılırken gemi alacaklısı hakkının diğer bütün adi ve rehinli alacaklarla ihtiyati ve icrai hacizli temin edilmiş olacaklardan ve hapis haklarından doğuş tarihine bakılmaksızın önce gelir ${ }^{5}$. İflas halinde ise üzerine ipotek tesis edilmiş bir geminin paraya çevrilmesi halinde gemi alacaklısı hakkı ipotekli alacaktan önce gelir.

Gemi alacaklısı haklarının kendi aralarındaki sırası ile TTK'nun 1235, 1248 ve 1249 ve 1250 . maddeleri gözetilerek belirlenir.

\section{III- Rehinli Alacaklar}

Rehinli alacaklar, mülkiyeti müflise ait malın rehni ile temin edilmiş olan alacaklardır. İ̈K'nun 206. maddesinde yer alan rehin kavramından ne anlaşılması gerektiği aynı kanunun 23. maddesinde belirtilmiştir. Hükme göre sadece rehin tabiri ipotek ve taşınır rehni tabirlerine giren taşınır ve taşınmaz rehinlerini ihtiva eder. İflas tasfiyesinde rehinli alacaklardan önce ödenmesi gereken alacaklar varsa önce bunlar ödenecek, sonra da rehinli alacaklıların rehin kapsamındaki alacakları ödenecektir. Ancak iflas masasına giren rehinli mallardaki rüçhan hakkından yararlanabilmek için bu malların tasfiye şekline ilişkin ilandan itibaren bir ay içinde iflas daire emrine verilmesi (İ̈K m. 219/4) gerekir (İ̈K md. 213, 231).

\footnotetext{
${ }^{4}$ Gümrük vergisi, bina ve arazi vergisi, veraset ve intikal vergisi ve motorlu taşıt vergisi, rehinli alacaklardan önce ödenmesi gereken kamu alacaklarıdır. Ayrıntılı bilgi için bkz. Deynekli, Adnan: İflasın Vergi Alacağına Tahsiline Etkisi, Ankara 1999, s. 114 vd.

${ }^{5}$ 19.HD, 2.7.1996, 4837/6950 (Deynekli, Adnan/Kısa, Sedat: Hacizde ve İflasta Sira Cetveli Ankara 2002 s. 692-693).
} 
Müflis tarafından bir alacaklı lehine üst sınır (limit) ipoteği verilmişse, limit dahilinde olan kısmın rüçhanlı, limit fazlasının adi alacak olarak sıra cetveline kaydedilmesi gerekir ${ }^{6}$.

İflasın açılmasıyla müflisin rehinle temin ettiği alacakların faizi merhunun satışına kadar devam eder ve bu faiz rehin alacaklısına rüçhanlı olarak ödenir ${ }^{7}$.

\section{1- Menkul Rehni}

Menkul rehni, bir alacağı temine yarayan, başkasına ait menkul mal veya hak üzerinde tesis edilen sınırlı bir ayni hak olup, alacaklıya borçlardan alacağını istifa edememesi halinde rehinli malın satış bedelinden olacağını istifa yetkisi veren bir haktır.

Menkul rehni çeşitlerine örnek olarak, ticari işletme rehni, maden rehni, hayvan rehni, motorlu taşıtların rehni, gemi rehni, hava aracı rehni, Tarım Kredi Kooperatiflerinin rehin hakkı ve hapis hakkını sayabiliriz.

Uygulamadaki önemi nedeniyle bunlardan sadece motorlu araçların rehni üzerinde duracağız.

Motorlu taşıtların rehnedilebilmesi için taraflar arasında bu konuda yapılmış bir rehin sözleşmesi gereklidir. Rehin sözleşmesi herhangi bir şekle tabi değildir. Ancak ispat yönünden motorlu taşıtların rehninin yazılı şekilde yapılması yararlı olur.

743 say1l Medeni Kanunun 853. maddesinde kanunen muayyen istisnalar haricinde bir menkulun ancak teslimi meşrut şekilde rehnedilebileceği hükme bağlanmıştı. Hükme göre rehneden menkulü elinde bulundurduğu sürece rehin alan alacaklı için rehin hakkı meydana gelmez. 4721 sayıl1 Medeni Kanunun 939. maddesi ile menkul malların rehni yönünden 743 sayılı MK'na 853. maddesine oranla değişik bir düzenleme yapılmıştır. Menkul malların rehni zilyedliğinin alacaklıya devri suretiyle olabileceği gibi (MK m. 939) bir sicile tescili zorunlu olan taşınır mallar üzerinde, zilyedlik devredilmeden de, taşınır malın kayıtlı olduğu sicile yazılmak suretiyle rehin kurulabilir (MK m. 940/2). Taşınır rehninin kurulmas1 yönünden ayrık düzenleme yapılmasının nedeni trafik siciline kayıtlı motorlu araçların rehni nedeniyle ortaya çıkan sorunları bir ölçüde gidermektedir. Yeni düzenleme ile motorlu araçlar teslime bağlı olarak rehnedilebileceği gibi trafik siciline rehin şerhi koymak suretiyle de rehnedilebilecektir.

${ }^{6} 11$. HD, 28.3.1990, 2168/2685 (Deynekli/Kısa- S1ra Cetveli 1996, s. 529).

712. HD 27.11.1984, 12704/12312 (Yasa HD, 1985/1 s. 120-121); 19. HD, 5.10.1992,

7716/4727 (Deynekli/Kısa - Sira Cetveli 1996, s. 720-721). 
Bir motorlu araç üzerinde birden fazla rehin kurulması halinde rehin hakkının sırası kuruluş tarihine göre belirlenir (MK m. 948/2).

Hükümde yer alan birden fazla rehinden anlaşılması gereken sonradan kurulan rehinlerle önceki rehinlerdir. Satış bedelinin bütün rehinli alacaklıların alacağını karşılanması halinde rehin sırasının önemi yoktur. Ancak satış bedeli bütün alacaklıların alacağını karşılamaması halinde anılan madde hükmüne menkul rehinlerin sırasının tayin edilmesi gerekir. Satış bedelinden öncelikle bütün alacaklıları ilgilendiren satış ve paylaştırma masraflarının çıkarılması (İ̈K. 151. maddesinin atfı nedeniyle 138. maddesine göre) daha sonra da rehinli alacaklılara sıralarına göre alacaklarının ödenmesi gerekir.

\section{2- Gayrimenkul Rehni}

Gayrimenkul rehni, ipotek veya ipotekli borç senedi veya irat senedi şeklinde tesis olunabilir (MK m. 850).

İflasta lehine üst sınır ipoteği tesis edilen alacaklının ipotek limitini oluşturan alacağının sıra cetveline öncelikli (rüçhanlı) alacak olarak kaydedilmesi, limit fazlasının ise adi alacak olarak sıraya yazılması gerekir.

Sözleşmeden doğan ipoteklerde sıra derecelere göre belirlenecektir. Derecenin boş bırakılması ancak sözleşmeden doğan ipoteklerde söz konusu olup, tescile tabi kanuni ipotekte önceki derecenin boş bırakılması mümkün değildir. Konunun daha iyi anlaşılabilmesi için örnek vereceğiz. Taşınmaz malikince birinci derece saklı tutulup, ikinci sırada sözleşme ile ipotek tesis edildikten sonra tescile tabi kanuni ipotek kurulduğu takdirde siralama şöyle olacaktır; Tescile tabi olmayan kanuni ipotek haklarından MK.nun 865 ve 867. maddelerinden doğan alacak ise bağl1 bulunduğu ipotekle aynı sırada örneğin ikinci derecede yer alan ipotekli alacaklı sigorta yaptırmışsa aynı sırada bu alacağını alacaktır. Saklı tutulan birinci dereceye bir ipotek tesis edildiği takdirde MK.nun 865 ve 867. maddelerindeki alacaklardan sonra birinci derecede yer alan alacak, daha sonra sırasıyla ikinci sıradaki alacak ve tescile tabi kanuni ipotek hakk1 yer alacaktır.

Sözleşme ile kurulan ipoteklerde ipotek hakkı diğer sınırlı ayni haklar (irtifak hakları ve gayrimenkul mükellefiyeti) karşısındaki sırası bir görüşe göre işgal eden derecenin sırasına göre değil, kendi tescil tarihine göre tesbit edilmelidir $^{8}$. Bir diğer görüşe göre ipotek haklarının diğer sınırlı ayni haklar karşısındaki sırası, rehnin tescil tarihine göre değil, işgal ettiği derecenin sırasına göre tesbit olunmalıdır'. İrtifak hakkı ve gayrimenkul mükellefiyeti terkin olunduğu tarihte, bu hakların sahipleri taşınmazın bedelinden haklarını almakta, sıra itibarıyla sonra gelen ipotekli alacaklara karşı rüçhanlıdırlar.

${ }^{8}$ Erel, Şafak: Gayrimenkul Rehninde Sıra Ankara 1974, s. 81'de belirtilen yazar.

${ }^{9}$ Erel, s. 81 . 
$\mathrm{Bu}$ hakların değeri tapu kütüğüne kayıtllysa, icra memurluğunda resen nazara alınacak, kayıtlı değilse, hak sahipleri talep ettikleri miktarı sıra cetvelinin düzenlenmesi sirasında icra memurluğuna bildirmeleri gerekecektir $^{10}$.

Bir alacak birden fazla taşınmaz ile teminat altına alınabilir (MK. m. 855). Birden fazla taşınmaz asıl borçluya ait olabileceği gibi, başka şahıslara da ait olabilir. Aynı alacak için rehnedilen birden fazla taşınmazların herbirinin borcun tamamından da sorumlu olmaları halinde toplu rehin sözkonusu olmaktadır. Birden fazla taşınmazın üzerinde tesis edilen rehinlerde her taşınmazın alacağı belli bir kısmını temin etmesi hali MK.nun 855 maddesinin ikinci fikrasında düzenlenmiştir. Taşınmazların aynı malike ve müteselsilen borçlu olan kişilere ait olması durumunda ipotek edilen her taşınmaz alacağın tamamı için teminat teşkil eder ${ }^{11}$. Bu durumda alacak muaccel olduğu takdirde alacaklı bu taşınmazların tamamının paraya çevrilmesini talep etmelidir. Buna karşılık icra memuru alacağ olanları paraya çevirir (MK. m. 873/son).

IV- Rehinli Olmayan Alacaklardan Önce Ödemesi Gereken Alacaklar (İflas Masrafları - Masa Borçları)

İIKK'nın 248. maddesinin kenar başlığı "iflas masrafları ve masanın borçları" şeklindedir. Madde metninde açıkça iflas masraflarının iflas alacaklarından önce ödeneceği belirtilmiş ise de masa borçlarından bahsedilmemiştir. Ancak masa borçlarının da iflas alacaklarından önce ödeneceği doktrin ve uygulamada kabul edilmektedir ${ }^{12}$.

İflas masraflarına örnek olarak, iflas kararının ilanına ve gereken yerlere bildirilmesine ilişkin masrafları, defter tutma, malların muhafaza ve satış masrafları, iflas idare memurlarının ücretleri, paraya çevirme ve paylaştırmaya ilişkin harç ve masrafları sayabiliriz.

Masa borçları ise, iflasın açılmasından sonra ve devamı sırasında masa namına tekeffül edilen ve onun tarafından ödenmesi gereken borçlardır. Masa borçlarına örnek olarak, iflas idaresinin müflisin sanat veya ticaretinin devamı çerçevesinde akdettiği borçları, iflas idaresinin sebepsiz iktisap, haksız fiillerinden doğan borçları ve iflas idaresi tarafından tutulan avukatın vekalet ücretini sayabiliriz ${ }^{13}$.

İflas masrafları ve masa borçlarına sıra cetvelinde yer verilmez. Ancak pay cetvelinde gösterilmelidir.

${ }^{10}$ Erel, s. 85.

${ }^{11}$ 19. HD. 20.3.1997, 458/2686 (Deynekli/Kısa - Sira Cetveli 2002 s. 732-733.

${ }^{12}$ Öztek, Selçuk: İflas Hukukunda Sıra Cetveli Prosedürü ve Sıra Cetveline Karşı Müracaat Yolları s. 14; Postacıoğlu, İlhan: İflas Hukuku İlkeleri İstanbul 1978 s. 205; 19. HD 27.2.1996, 22/1568 (Deynekli/Kısa- Sira Cetveli 2002 s. 749).

${ }^{13}$ Öztek, s. 17-18. 


\section{V- Rehinli Olmayan Alacaklar}

Rehinli olmayan alacaklar kapsamına imtiyazlı alacaklar ile adi alacaklar girmektedir. İmtiyazlı alacakları İIK'nun 206. maddesi kapsamına giren imtiyazlı alacaklar ile özel kanunlarda imtiyazlı olduğu belirtilen alacaklar olarak ayırıma tabi tutabiliriz.

\section{1- İmtiyazlı Alacaklar}

İmtiyazlı alacaklar, adi alacaklara göre önce ödenmesi gereken alacaklardır. İmtiyazlı alacaklar İIK'nun 206. maddesinde ve bazı özel kanunlarda düzenlenmiştir.

Buradaki imtiyaz, imtiyazlı olanın şahsına değil, alacağa ilişkindir. $\mathrm{Bu}$ nedenle alacak devredilmeden imtiyaz hakkının devri mümkün değildir ${ }^{14}$. İmtiyazlı alacağın temliki halinde, imtiyaz hakkı temellük eden alacaklıya geçebileceği gibi, alacaklının ölümü halinde mirascılara ve borcu ödeyerek alacaklının haklarına halef olan kefilede geçecektir ${ }^{15}$. Kanunda aksine bir hüküm bulunmadıkça imtiyaz hakkı sahibi bu imtiyazından feragat edebilir. İmtiyazlı alacaklını feragatı olmadığı halde bulunması gereken sıraya alınmaması halinde bu alacaklının sıra cetveline şikayet yoluyla itiraz etmesi gerekir $^{16}$. İ̈K.nun 206. maddesindeki imtiyazlı alacaklar hacizde sıra cetveli düzenlenirken de dikkate alınmalıdır. Nitekim İİK.nun 140. maddesinin 2. fikrasında, hacizde sira cetvelinde alacaklıların 206. madde gereğince iflas halinde hangi sıraya girmeleri lazım geliyorsa o sıraya kabul olunacağ 1 belirtilmiştir. Bununla beraber hacizde sira cetvelinde, İIK.nun 206. maddesinin ilk üç sırasındaki alacaklar için muteber olan tarih haciz talep tarihidir (İ̈K. mad. 140/son).

İIK'nun 206. maddesinde yapılan değişiklik sonucu dört sıra kabul edilmiştir. İlk iki sıradaki alacaklar yönünden hacze iştirak ilgili olarak iflasın açılma tarihi kabul edilmiştir. Üçüncü sırada özel kanunlarında imtiyazlı olduğu belirtilen alacaklara yer verilmiştir. Bu sırada iflasın açılma tarihi yönünden bir düzenleme getirilmediği için İIK'nun 140/son maddesinde 206. maddedeki değişikliğe rağmen değişiklik yapılmadığından hacze iştirak yönünden üçüncü sırada yer alan alacakların imtiyaz süresi bakımından uyuşmazlıklar çıkabilecektir.

\section{a- İİK'nun 206. Maddesinde Öngörülen İmtiyazlı Alacaklar}

İIK'nun 206. maddesinde ilk beș sırada imtiyazlı alacaklar öngörülmüş iken 4949 sayılı Kanunla yapılan değişiklik sonucu ilk üç sıradaki alacaklara imtiyaz tanınmıştır.

\footnotetext{
${ }^{14}$ Postacıoğlu, s. 194; Belgesay, Mustafa Reşit: İcra ve İflas Hukuku C. II 1953 s. 103.

${ }^{15}$ Ansay, s. 267; Kuru C. III, s. 3011; Postacioğlu, s. 194.

${ }^{16}$ Postacioğlu, s. 194.
} 


\section{aa- Birinci Sira}

A - İşçilerin, iş iliş̧isine dayanan ve iflasın açılmasından önceki bir yıl içinde tahakkuk etmiş ihbar ve kıdem tazminatları dahil alacakları ile iflas nedeniyle iş ilişkisinin sona ermesi üzerine hak etmiş aldıkları ihbar ve kıdem tazminatı alacakları imtiyazlıdır.

İşçilerin iş ilişkisine dayanan iflasın açılmasından önceki bir yıl içinde tahakkuk etmiş alacakları (örneğin ücret alacağı) imtiyazlıdır. Bir yıllık süreden önce doğmuş işçilik alacakları imtiyazlı değildir. $\mathrm{Bu}$ nedenle dördüncü sıraya kaydedilmelidir. İşçi iflas tarihinden önce işten ayrılmışsa, iflas tarihinden geriye doğru bir yıllık sürenin başlangıcından işten ayrılma tarihine kadar olan süredeki ücret alacağı imtiyazlıdır. İflasın açılmasından bir yıl önce işten ayrılan işçinin işçilik alacakları imtiyazlı değildir, bu nedenle dördüncü sırada yer almalıdır.

Sürelerin hesaplanmasında iflasın açılmasından önce mühlet de dahil olmak üzere geçirilen konkordato süresi, iflasın ertelenmesi süresi ve alacak hakkında açılan davanın devam ettiği süre ile terekenin iflas hükümlerine göre tasfiyesinde, ölüm tarihinden tasfiye kararı verilene kadar geçen süreler dikkate alınmaz (İ̈K m. 206/son). Bu hüküm 4949 sayılı Kanunla yapılan değişiklikten sonra düzenlenecek sıra cetvellerinde uygulanacaktır (4949 say11 Kanun Geçici madde 5 bend 31).

İşçi k1dem ve ihbar tazminatları yönünden İIKK'nun 206. maddesinin F bendinde bir süre ile sınırlı olmadan imtiyaz tanınmıştı. Yeni düzenleme ile iş akdinin iflas nedeniyle feshi halinde kıdem ve ihbar tazminatı alacağ 1 süreye bakılmadan imtiyazlı kabul edilmiştir (4949 sayılı Kanunla değişik 206. maddesi A bendi). İflastan başka bir nedenle iş ilişkisinin sona ermesi halinde ise diğer iş̧̧ilik alacakları gibi iflasın açılmasından önceki bir yıl içinde tahakkuk etmiş ihbar ve kıdem tazminatı alacaklarına imtiyaz tanındığı görüşündeyim. Maddenin düzenleniş tarzı böyle bir yorum yapmaya müsait görünmektedir.

İşçilerin iş ilişkisine dayanmayan alacaklarına birinci sıra da imtiyaz tanınmadığından dördüncü sırada işlem görecektir.

B- İşverenlerin, işçiler için yardım sandıkları veya sair yardım teşkilatı kurulması veya bunların yaşatılması maksadıyla meydana gelmiş ve tüzel kişilik kazanmış bulunan tesislere veya derneklere olan borçları birinci sirada imtiyazlidır.

C - İflasın açılmasından önceki son bir yıl içinde tahakkuk etmiş olan ve nakden ifası gereken nafaka alacaklarına birinci sırada imtiyaz tanınmıştır.

4949 sayılı yasayla yapılan değişiklikten önce ilama bağlanmış ve paylaştırmaya kadar işleyecek karı, koca ve çocuk nafakaları birinci sırada imtiyazlı olarak sayılmıştı. Ana, baba ve kardeş nafakalarının bu hüküm 
kapsamında olmadığ 1 kabul edilmekteydi ${ }^{17}$. Yeni düzenleme ile ayrım yapılmadan her türlü nafaka alacakları iflasın açılmasından önceki son bir yıl içinde tahakkuk etmiş olması şartıyla birinci sırada imtiyazlı kabul edilmiştir. İflasın açılmasından önceki son bir yıldan daha önce tahakkuk etmiş nafaka alacakları dördüncü sırada işlem görecektir.

\section{bb - İkinci sıra}

Velayet ve vesayet nedeniyle malları borçlunun idaresine bırakılan kimselerin bu ilişki nedeniyle doğmuş olan alacakları ikinci sırada imtiyazlidır.

Ancak bu alacaklar vesayet veya velayeti devam ettiği müddet yahut bunların bitmesini takip eden yıl içinde iflas açılırsa imtiyazlı alacak olarak kabul olunur. Bir davanın veya takibin devam ettiği süreler hesaba katılmaz (İ̈K m. 206).

Velayet veya vesayet ile veya malların idaresi ile ilgili olmayan alacakların imtiyaz hakkı bulunmamaktadır. Ana babasıyla birlikte yaşayan reșit çocukların, ana babasından olan alacakları hacze takipsiz iștirak edebilirse de ikinci sırada imtiyaz hakkı tanınmamıştır ${ }^{18}$.

\section{cc - Üçüncü sıra}

Özel kanunlarında imtiyazlı olduğu belirtilen alacaklara üçüncü sırada imtiyaz tanınmıştır.

Özel kanunlarda düzenlenen bazı alacakların diğer alacaklara göre imtiyazlı olduğu belirtilmiş, ancak İIKK.nun 206. maddesinde öngörülen imtiyazlı alacaklardan önce mi, yoksa sonra $\mathrm{m}$ ödeneceği belirtilmemişti. Bu alacakları İIK.nun 206. maddesindeki sıralardan birine sokma imkânı olmadığından İIKK.nun 206. maddesindeki imtiyazlı alacaklardan önce ödeneceği kabul edilmekteydi ${ }^{19}$.

aaa- Kat Mülkiyeti Kanununun 22/son Maddesinde Öngörülen Alacak

Kat maliklerinin, gider borcunu ödemeyen kat maliklerinden olan alacaklarının öncelikli olduğu Kat Mülkiyeti Kanununun 22/son maddesinde belirtilmiștir. Buradaki öncelik, aynı maddenin 2. fikrasında düzenlenen kanuni ipoteğin tescilini istemekten ayrı bir haktır ve ipotek tescil edilmemiş

\footnotetext{
${ }^{17}$ Berkin, Necmeddin: İflas Hukuku İstanbul 1972, s. 295; Kuru, C III, s. 3012; Deynekli/Kısa - Sira Cetveli 2002 s. 610.

${ }^{18}$ Ansay, s. 262.

${ }^{19}$ Kuru, C. III s. 3008; Deynekli/Kısa - Sira Cetveli 2002 s. 605; Tercan, Erdal: 4389 say1l Bankalar Kanunu'na Göre Tasarruf Mevduatı Sigorta Fonu'nun ve Tasarruf Mevduatı Sahibi Alacakların, Bir Bankanın İflası Halinde, İflas Masasına İmtiyazlı Alacaklı Olarak Yazılmaları (Batider Haziran 2003 C. XXII s. 33).
} 
olsa bile ortak gider alacağı önceliklidir ${ }^{20}$. Ancak, maddede bu alacağın İIK.nun 206. maddesindeki alacaklardan hangisine gireceği açıklanmadığından farklı yorumlara sebep olmuştur.

Tekinay, bu düzenleme ile İIKK.nundaki sıraların bozulmak istenmesini kabul edilemeyeceğini, bu nedenle ortak gider alacağının, İ̈K.nun 206. maddesinde sıraları gösterilen imtiyazlı alacakların sonuncusu olması gerektiği görüşündedir ${ }^{21}$.

Kuru, bu alacağın İIKK.nun 206. maddesindeki siralardan birine sokmaya imkan olmadığından, İİK.nun 206. maddesindeki imtiyazlı alacaklardan önce ödenmesi gerektiği görüşündedir ${ }^{22}$.

4949 sayılı Kanunla yapılan değişiklik sonucu bu alacak üçüncü sırada imtiyazlı kabul edildiğinden tartışmaların önemi kalmamıştır.

İflasın açılmasından sonra doğan ortak gider alacağı konusunda bir düzenleme yoktur. Federal Mahkeme bir kararında "müflisin müşterek mülkiyet payının değerini muhafaza eden ortak giderlerin masa borcu olarak kabul edilerek öncelikle ödenmesi gerektiğini” belirtmiştir ${ }^{23}$. Türk Hukukunda da iflasın açılmasından sonra doğan ortak gider borcunun, masa borcu olarak ödeneceği ileri sürülmüştür ${ }^{24}$. Yargıtay bir kararında "müflise ait gayrimenkulün değerini muhafaza eden bakım ve idare masrafının masa borcu olduğunu kabul etmiştir ${ }^{25}$.

\section{bbb - HUMK.nun 417. Maddesinden Doğan Alacak}

HUMK.nun 417. maddesinde adli yardımdan yararlanma durumunda diğer tarafın mahkumiyeti halinde istifade olunamayan adli yardım masraflarının, alınan ilamın icrasında, imtiyazlı olarak tahsil edileceğ öngörülmüştür. Buradaki imtiyaz, dava sonucu kazanılan belirli mal veya para üzerindeki imtiyaz olup, İİK.nun 4949 sayılı Kanunla Değişik 206. maddesine göre üçüncü sırada işlem görecektir.

\section{ccc - İIK.nun 36. maddesinde Öngörülen Tehiri İcra Teminatı}

İIK.nun 36. maddesinin 1. fikrasına göre ilamı temyiz eden borçlunun, icranın geri bırakılması için teminat vermesi zorunludur. Anılan yasa maddesinin son fikrası uyarınca ilamın Yargitay'ca onanması halinde alacaklının talebi üzerine başka bir işlem gerekmeksizin teminata konu olan

${ }^{20}$ Tekinay, Selahattin Sulhi: Eşya Hukuku İstanbul 1984 s. 672.

${ }^{21}$ Tekinay, s. 672.

${ }^{22}$ Kuru C. III, s. 3008.

${ }^{23}$ BGE, 106 III 118; JDT 1982. II. 151 (Öztek, s. 18'den naklen).

${ }^{24}$ Öztek, s. 20.

${ }^{25}$ 19. HD. 4.7.1995, 5924/6110 (Deynekli/Kısa - Sira Cetveli 2002 s. 750-751). 
para alacakliya ödenir, mal ve haklar ise, malın nev'ine göre icra müdürlügünce paraya çevrilir. İlam alacaklısının para veya mal ve hak olarak gösterilen teminat üzerinde üçüncü sırada imtiyaz hakkı vardır.

\section{Alacak}

*ddd - Sigorta Murakebe Kanunun 14/II. Maddesinden Doğan

Sigorta şirketleri sigorta sözleşmelerinden doğan taahhütlerine karşılık olmak üzere, sigorta primleri ile orantılı olarak teminat göstermek zorundadirlar (7397 Sayılı Kanunun 12/I. maddesi). Bu teminatlar, sigortalıların tüm alacakları ödenmeden iflas veya tasfiye masasına dahil ve başka nitelikteki alacaklar için dava edilemez veya icra takibine konu yapılamaz (7397 Sayılı Kanunun 14/II. maddesi). Madde hükmüne göre sigortalıların teminatlar üzerinde diğer alacaklılara göre imtiyaz bulunduğu ve bu imtiyazın İ̈K.nun 206. maddesindeki imtiyazlardan önce geleceği kabul edilmekteydi ${ }^{26}$.

İIK'nun 206. maddesinde 4949 sayılı Kanunla yapılan değişiklikten sonra bu alacak üçüncü sırada işlem görecektir.

Burada as1 üzerinde durulmas1 gereken sigortalıların teminatla karşılanmayan alacaklarıdır. Bu alacakların iflas masasına İIK'nun 206. maddesiyle sigortalı üçüncü sırada iştirak edeceği hükme bağlanmıştır. 4949 sayılı Kanunla yapılan değişiklik sonucu özel kanunlarda imtiyazlı olduğu belirtilen alacakların üçüncü sırada işlem göreceği hükme bağlanmıştır. Özel kanunlarında İIK'nun 206. maddesinde gireceği sıra gösterilen alacakların değişiklikten sonra hangi sırada işlem göreceği konusunda bir düzenleme yapılmamıştır. $\mathrm{Bu}$ nedenle konu uygulamada tereddütlere yol açacak nitelikte gözükmektedir.

Özel kanunlarında İIK'nun 206. maddesinde gireceği sıra gösterilen alacaklar için 4949 sayılı Kararla değişik İIK'nun 206. maddesinde ayrı bir düzenleme yapılmadığından bunların da dördüncü sırada işlem göreceği görüşü ileri sürülebilir. Maddenin gerekeceği bu görüşü destekler niteliktedir.

\section{eee - Avukatlık Kanununun 166. Maddesinden Doğan Alacak}

Avukat, sözleşme ile kararlaştırılan ve hakim tarafindan takdir olunan ücretinden dolayı, kendi çalışması sonucunda müvekkilini muhafaza ettiği veya kazandığı mallar ve davadaki diğer taraftan ilam gereğince tahsil edilecek para yahut alınacak mallar üzerinde diğer alacaklılara nazaran rüçhan hakkını haizdir. Rüçhan hakk1, vekaletnamenin düzenlenme tarihinde, vekaletname umumi ise iş sahibi adına ücret konusu işten dolayı ilk yapılan resmi başvurma tarihine göre sıra alır (1136 sayılı Kanunun 166/II. maddesi). Avukatın ölümü halinde, mirasçılarına intikal eden

\footnotetext{
${ }^{26}$ Deynekli/Kısa - Sira Cetveli 2002 s. 607.
} 
avukatlık ücreti alacakları da, avukat alacakları gibi rüçhanlıdır (1136 sayılı Kanunun 166/IV. maddesi).

İş sahibinin iflası halinde vekalet ücreti alacağı da sözkonusudur. Rüçhan hakkı tanınırken İIKK'nun 206. maddesinin 1. fikrası hükmü saklı tutulmuştur. Saklı tutulan hükme göre avukatın vekalet ücreti alacağı rehinli alacaklar ile eşya ve gayrimenkulün aynından kaynaklanan kamu alacaklardan sonra, 206. maddede imtiyazlı alacak olarak belirtilenlerden önce ödeneceği kabul edilmekteydi ${ }^{27}$.

4949 sayılı Kanunla yapılan değişiklikten sonra düzenlenecek sıra cetvellerinde avukatın vekalet ücreti alacağına üçüncü sırada imtiyaz tanınacaktır.

fff- 1518 Sayılı Tarım Kredi Kooperatifleri ve Birlikleri Kanunun 16/son Maddesinde Öngörülen Alacak

1581 Sayılı Kanunun 16. maddesinin 2. fikrası uyarınca Tarım Kredi Kooperatiflerine mevduatı kabul ve bankacılık işlemleri yapma yetkisini tanımıştır. Anılan yasanın 16. maddesinin son fikrasına göre de, tasarruf mevduatı sahiplerine mevduatlarının yarısı için bu mevduatı kabul etmiş olan kooperatif ve bölge birliklerinin aktifinde mevcut bütün kıymetler üzerinde imtiyaz hakkı tanınmıştır. Tasfiye halinde, tasarruf mevduatının imtiyazlı kısmı, tasfiye neticesi beklenmeksizin sahiplerine ödenecektir. İIK'nun 206. maddesinde 4949 sayılı Kanunla yapılan değişiklik sonucu bu alacaklarda üçüncü sırada işlem görecektir.

c- 4389 Sayılı Bankalar Kanununun 16/4 ve Geçici 3. Maddesinde Öngörülen Tasarruf Mevduatı Sigorta Fonu Alacağı

4389 sayılı Bankalar Kanununun 16. maddesine göre bir bankanın bankacılık işlemleri yapma ve mevduatı kabul etme izninin kaldırılması halinde yönetim ve denetimi Tasarruf Mevduatı Sigorta Fonuna intikal eder (1. bend). Tasarruf Mevduatı Sigorta Fonu, yönetim ve denetimi kendisine intikal eden bankadaki sigorta mevduatı doğrudan veya ilan edeceği başka bir banka aracılığı ile ödeyerek, mevduat sahipleri yerine bankanın doğrudan doğruya iflasını ister (3. bend). İflas kararı alınması halinde Fon, iflas masasına imtiyazlı alacak olarak iştirak eder (4. bend).

İflasına hükmolunan bankanın Fona olan borçları, masanın nakit durumuna göre sıra cetvelinin kesinleşmesi beklenmeksizin ödenir (m. 16/5).

4389 sayılı Bankalar Kanununun geçici 3. maddesinde tasfiye halindeki müflis TYT Bank A.Ş., İmpexbank A.Ş. ve Marmara Bankası A.Ş.'den tasarruf mevduatı alacağı bulunanlara Fon tarafindan yapılacak ödemeler hükme bağlanmıştır. Fon, maddede öngörülen esaslar çerçevesinde yapacağı

\footnotetext{
${ }^{27}$ Kuru, C. III s. 3009; Deynekli/Kısa - Sira Cetveli 2002 s. 607.
} 
ödemelerle ilgili olarak iflas masalarına imtiyazlı alacaklı sıfatıyla iştirak eder (son fikra).

Tasarruf Mevduatı Sigorta Fonunun imtiyazının İ̈K'nun 206. maddesindeki imtiyazlarda önce geleceği kabul edilmekteydi ${ }^{28}$.

İIK'nun 206. maddesinde 4949 sayılı Kanunla yapılan değişiklikle özel kanunlarında imtiyazlı olduğu belirtilen tüm alacakların üçüncü sırada yer alacağı hükme bağlanmıştır. Bu durumda TMSF'nın alacağı da 4949 sayılı Kanunun yürürlüğe girdiği tarihten sonra düzenlenecek sıra cetvellerinde üçüncü sırada yer alacaktır.

b- IíK'nun 206. Maddesinde Öngörülmeyen Ancak Bu Maddede Gireceği Sıra Belirtilen Özel Kanunlardan Doğan Alacakların Sırası

Bazı alacakların imtiyazlı olduğu İIK'nın, 206. maddesinde öngörülen hangi sıraya gireceği özel kanunlarında gösterilmiștir. Bu alacaklar, 4792 sayılı Sosyal Sigortalar Kurumu Kanunu'nun 21. maddesinde öngörülen alacak, Bağ-Kur Kanunu'nun 17. maddesinde öngörülen alacak, Sosyal Hizmetler ve Çocuk Esirgeme Kurumu Kanunu'nun 31/1. maddesinde öngörülen alacak, Ordu Yardımlaşma Kurumu Kanunu'nun 37. maddesinde öngörülen alacaktır. Sigorta Murakebe Kanunu'nun 22/son maddesinde öngörülen alacağın İIK'nun 206. maddesindeki üçüncü siraya gireceği hükme bağlanmıştır. Bu alacağın İIK'nun 206. maddesinde 4949 sayılı Kanunla yapılan değişiklikten sonra dördüncü sırada yer alması gerektiği yukarıda açıklamışı ${ }^{29}$.

Diğer alacakların devlet alacağı derecesinde imtiyazlı olduğu belirtildiğinden İIK'nun 206. maddesinde öngörülen beşinci sırada işlem göreceği kabul edilmekteydi ${ }^{30}$.

İIK'nun 206. maddesinde 4949 sayılı Kanunla verilen değişiklik sonucu devlet alacağına adi alacaklardan önce beşinci sırada tanınan imtiyaz ortadan kaldırılmış ve bu husus değişiklik gerekçesinde vurgulanmıştır. Bu nedenle yukarıda sayılan Kamu alacağı niteliğinde alacaklar adi alacaklarla birlikte dördüncü sırada yer alacaktır.

4389 say1l Bankalar Kanunu'nun 10/2-c maddesi ile tasarruf mevduat1 sahiplerine imtiyaz tanınmıştır. Hükme göre bir bankanın iflası halinde tasarruf mevduatı sahipleri, Fonun alacaklarından sonra gelmek üzere tasarruf mevduatlarının sigortaya 206. maddesinde öngörülen birinci sıra anlamında imtiyazlı olduğu hükme bağlandığından tasarruf mevduatı sahipleri İIK'nun 206. maddesinde öngörülen birinci sırada sayılan alacaklılarla aynı sıraya girmekteydi.

\footnotetext{
${ }^{28}$ Deynekli/Kısa - Sira Cetveli 2002 s. 606; Tercan, 4389 say1lı Bankalar Kanununa göre ... s. 33.

${ }^{29}$ Bkz. Yuk. dipnot 26 civar1.

${ }^{30}$ Deynekli/Kısa - Sira Cetveli 2002 s. 614-615.
} 
Acaba İIK'nun 206. maddesinde 4949 sayılı Kanunla yapılan değişiklikten sonra tasarruf mevduatı sahipleri yine birinci sırada mı, veya üçüncü sırada $m ı$ yahut dördüncü sırada $m ı$ işlem görecektir?

Bankalar Kanununun 10/2-c maddesinde tasarruf mevduatı sahiplerinin alacağının açıkça İIK'nun 206. maddesindeki birinci sıraya gireceği hükme bağlandığından ilk bakışta 4949 sayılı Kanunla yapılan değişiklikten sonra da birinci sıraya gireceği düşünülebilir. Fakat kanun koyucunun amacı özel kanunlarda imtiyazlı olduğu belirtilen alacakları üçüncü sıraya almaktır (madde gerekçesi). Bu amaç gözetildiğinde tasarruf mevduatı sahiplerinin alacağının üçüncü sırada işlem görmesi gerektiği ileri sürülebilir. $\mathrm{Bu}$ durumda da Tasarruf Mevduatı Sigorta Fonu alacağ 1 ile tasarruf mevduatı sahiplerinin sigorta kapsamında bulunmayan alacakları üçüncü sırada işlem görecektir. Bu sonuç Bankalar Kanununda TMSF'na ve tasarruf mevduatı sahiplerine farklı sıralarda imtiyaz tanınmasındaki amaç ile bağdaşmaz. $\mathrm{Bu}$ nedenle tasarruf mevduatı sahiplerinin sigorta kapsamında bulunmayan alacaklarının dördüncü sırada adi alacak olarak işlem görmesi son düzenlemedeki kanun koyucunun amacına uygundur.

\section{2- Adi Alacaklar}

Rehinli ve imtiyazlı kabul edilmeyen bütün alacaklar İIK'nın 206. maddesindeki dördüncü sıraya girer. Rehinli alacakların rehin bedeli ile karşılanmayan kısmının da bu sıraya girmesi gerekir. Ayrıca imtiyaz hakkının süre ile sınırlandığ 1 durumlarda, sürenin dışında kalan alacaklar da sıra cetvelinde dördüncü sıraya alınırlar.

\section{VI - Sıralar Arasındaki İlişki}

Sıralar arasındaki ilişki İIK'nın 207. maddesinde düzenlenmiştir. Her sıranın alacaklıları aralarında eşit hakka sahiptir. $\mathrm{Bu}$ nedenle, bir sıraya isabet eden para bu sırada yer alan bütün alacaklılara alacakları nisbetinde eşit olarak paylaştırılır ${ }^{31}$. Aynı sırada yer alan alacakların birbirlerine karşı önceliği bulunmamaktadır.

Paylaştırmada, önceki sırada yer alan alacaklardan ödenmeden sonraki sıraya geçilemez. Bütün alacakların ödenmesinden sonra bakiye kalırsa İIK'nın 196/son maddesi uyarınca iflastan sonra işleyen faizler ödenir.

Faizlerin ödenmesinde İIK'nın 206. maddesindeki sıraya uyulup uyulmayacağı konusunda kanunda açıklı yoktur. İmtiyaz hakkı kanunlarımızda sınırlı olarak düzenlendiğinden faizlerin ödenmesinde aynı sıra takip edilmeyerek faiz alacakları garameten ödenmelidir ${ }^{32}$.

\footnotetext{
${ }^{31}$ Uyar, Talih: İcra ve İflas Kanunu Şerhi C. II, s. 2126.

${ }^{32}$ Deynekli/Kısa - Sira Cetveli 2002, s. 616.
} 